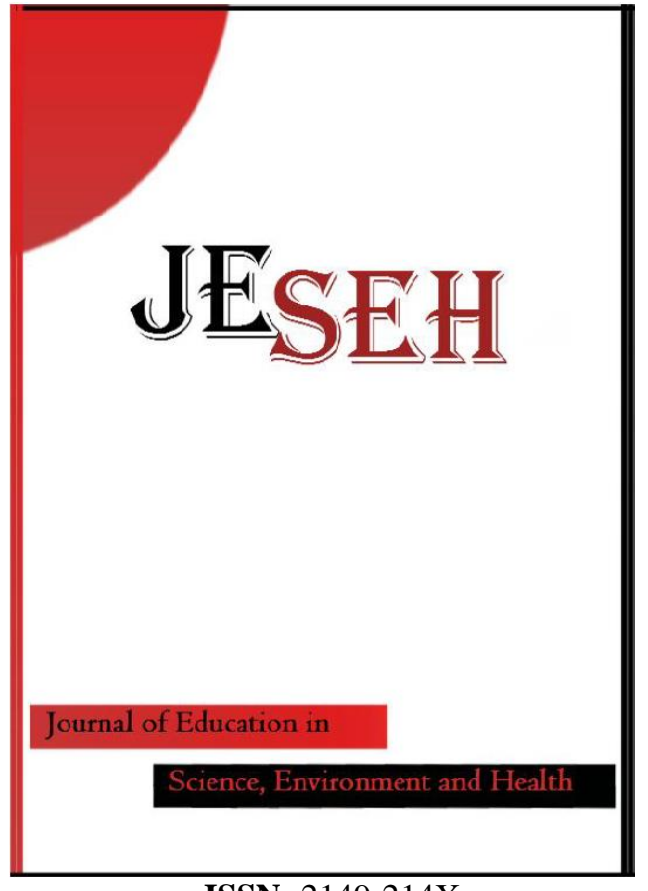

ISSN: $2149-214 \mathrm{X}$

\section{Journal of Education in Science,} Environment and Health

www.jeseh.net

Exploring Medical Students' Readiness for E-Learning and Knowledge Sharing Behaviors in Emergency Remote Learning Environments during Covid-19

Gunes Korkmaz ${ }^{1}$, Cetin Toraman ${ }^{2}$

${ }^{1}$ Ozel Ege High School

${ }^{2}$ Canakkale Onsekiz Mart University

To cite this article:

Korkmaz, G. \& Toraman, C. (2021). Exploring medical students' readiness for e-learning and knowledge sharing behaviors in emergency remote learning environments during Covid19. Journal of Education in Science, Environment and Health (JESEH), 7(3), 259-268. https://doi.org/10.21891/jeseh.960141

This article may be used for research, teaching, and private study purposes.

Any substantial or systematic reproduction, redistribution, reselling, loan, sub-licensing, systematic supply, or distribution in any form to anyone is expressly forbidden.

Authors alone are responsible for the contents of their articles. The journal owns the copyright of the articles.

The publisher shall not be liable for any loss, actions, claims, proceedings, demand, or costs or damages whatsoever or howsoever caused arising directly or indirectly in connection with or arising out of the use of the research material. 


\title{
Exploring Medical Students' Readiness for E-Learning and Knowledge Sharing Behaviors in Emergency Remote Learning Environments during Covid-19
}

\author{
Gunes Korkmaz, Cetin Toraman
}

\begin{tabular}{|c|c|}
\hline Article Info & Abstract \\
\hline Article History & $\begin{array}{l}\text { The rapid spread of Covid-19 pandemic has profoundly affected the educational } \\
\text { practices all over the world and educational institutions sought ways to adapt to }\end{array}$ \\
\hline $\begin{array}{l}\text { Published: } \\
\text { 01 July } 2021\end{array}$ & $\begin{array}{l}\text { this unprecedented situation. The problem was that most of these institutions, } \\
\text { educators and students were not ready for online learning environments and the }\end{array}$ \\
\hline $\begin{array}{l}\text { Received: } \\
03 \text { February } 2021\end{array}$ & $\begin{array}{l}\text { stakeholders were not yet sure about how to share the knowledge in a better way. } \\
\text { This study aims to examine the medical students' readiness for e-learning and } \\
\text { knowledge sharing behaviors in online learning environments during Covid-19, }\end{array}$ \\
\hline $\begin{array}{l}\text { Accepted: } \\
17 \text { June } 2021\end{array}$ & $\begin{array}{l}\text { and to analyze the relationship between these variables. The study has been } \\
\text { designed according to correlational research methodology. The data were } \\
\text { collected using "Knowledge Sharing Behavior in Online Learning Environments }\end{array}$ \\
\hline Keywords & $\begin{array}{l}\text { Scale" and "E-Learning Readiness Self-Assessment Instrument". } 725 \text { medical } \\
\text { students participated in the study. Students' readiness for e-learning and }\end{array}$ \\
\hline Covid-19 & knowledge sharing behaviors were analyzed using descriptive statistics, and the \\
\hline Emergency remote & relationship between the variables was modeled using multivariate regression \\
\hline learning & equation. The results revealed that the students with high ability to use computer, \\
\hline E-learning & mobile phone and tablet PC have higher readiness level for e-learning in terms of \\
\hline Readiness & technology access, technical skills, online relationships, motivation, online skills, \\
\hline $\begin{array}{l}\text { Knowledge sharing } \\
\text { Medical students }\end{array}$ & importance of success. Similarly, they have a higher level of knowledge sharing \\
\hline & \\
\hline
\end{tabular}

\section{Introduction}

Covid-19 pandemic has had great societal and economic impacts worldwide, and, without doubt, education has been one of the most affected sectors at all levels. Due to the rapid spread of coronavirus, countries had to close down the schools and universities, and had to implement emergency actions to sustain education through digital learning environments. We call these actions "emergency" as it was neither an expected condition to emerge nor an alternative to be chosen, but a challenge to prevent the learning loss of the students and enable the continuity of education. In this respect, the way we consider "education" in online learning environments should be redefined.

The type of education rapidly developed as a response to a crisis situation such as Covid-19 pandemic is called "emergency remote learning", and as a temporary way to educate the students, it differs from the concept of "online learning" which is planned in advance with appropriately chosen resources and infrastructure in a carefully designed virtual environment (Affouneh et al., 2020; Cameron-Standerford et al., 2020; Hodges et al., 2020; Wang et al., 2020). On the contrary, online learning or e-learning refers to careful instructional design and planning, using a systematic model for design and development in the presence of different types of interaction rather than information transmission (Hodges et al., 2020). Within this context, we can understand that "emergency remote learning" and "online learning" are different terms.

Although remote learning has certain advantages in that it has a flexible and comfortable educational environment, it is better for time utilization, the courses can be recorded used again when needed (Shim \& Lee, 2020), and it enables self-paced and self-directed learning (Adedoyin \& Soykan, 2020; Hodges et al., 2020), it has also some disadvantages for the learners: having difficulty in accessing to digital devices with internet connection (Ferri et al., 2020), not being able to receive instant feedback from instructors as well as their peers, lack of interaction between the learners, poor communication with the instructor as well as inability to collaborate effectively with classmates (Arkorful \& Abaidoo, 2015; Shim \& Lee, 2020). Similarly, socially disadvantaged groups encounter difficulties in meeting the basic conditions required by online learning (Ferri, Grifoni \& Guzzo, 2020). Another problematic issue related to emergency remote learning is that fields that 
require hands-on practical experiences may be more difficult to study through e-learning (Arkorful \& Abaidoo, 2015) since these fields are based on learning through practical and clinical practice (e.g., medical students, engineering students, etc.).

Readiness for e-learning can be defined as being mentally or physically prepared for online learning experience (Watkins et al., 2004). Therefore, it requires certain abilities that students should develop before engaging with online learning materials (Pillay et al., 2007). Watkins et al. (2004) suggested that these abilities can be grouped under the dimensions of technology access, technology skills, online relationships, motivation, online skills and importance of success. While readiness for e-learning clearly involves the technical skills of computer usage and site navigation, there are also issues that may be related to effective student engagement with online learning (Smith, 2005). Knowledge sharing behavior is one of them. This concept refers to exchanging experiences and knowledge with peers in classes, teams, or communities (Wang \& Noe, 2010) and how well team members share information to perform their tasks (Han et al., 2018). In other words, knowledge sharing is a set of behaviors that involve the exchange of information, sharing, and donating task-relevant ideas, and suggestions among a group of people (Elrehail et al., 2018). Ma and Yuen (2011) define this term as the online communication of knowledge so that knowledge is learned and applied by individuals. Chao et al. (2011) suggested that there is a strong relationship between knowledge sharing and online learning interaction. Therefore, online learning environments should be designed to promote student engagement, student-student, student-instructor interactions (Bolliger \& Martin, 2018).

Given the potential for more difficult days to come, we can state that emergency remote learning will have an even more critical role for the societies (Korkmaz \& Toraman, 2020). This implies that considering this situation as temporary and reckoning that we'll get back to "normal" soon seems to be far away from the reality. So, how well are/were the students prepared to learn online before the pandemic? Are they getting better at learning in digital environments? What is the level of student interaction and engagement in remote learning environments? Do they get enough opportunities to share the knowledge with their peers or engage with others? Are online practices enough to provide medical students with certain professional skills and competences? These questions are still critical as it seems that online learning will remain important in the agenda of many countries for many years. Since there are not many studies regarding students' readiness to emergency remote learning and their knowledge sharing behaviors in online learning environments, there is still a need to focus more on these issues that motivate students to learn collaboratively in a more social environment.

This study aims to examine the medical students' readiness for e-learning and knowledge sharing behaviors in online learning environments during Covid-19, and to analyze the relationship between these variables. The following are the research questions of this study:

(1) How do medical students perceive themselves in terms of knowledge sharing in online learning environments?

(2) How do medical students perceive themselves in terms of readiness for e-learning?

(3) What is the prediction level of readiness for e-learning on knowledge sharing behaviors in online learning environments?

(4) Is there a significant difference between the students' readiness for e-learning and knowledge sharing behaviors in online learning environments according to their computer, mobile phone and tablet PC using skills? (5) Is there a significant difference between students' e-learning readiness and knowledge sharing levels according to time spent on computer, mobile phones, tablet PC, etc.?

In the following sections, we presented the research design, gave information about the participants, described how we collected the data, and they were analyzed in the method; the results section was structured following the same order with the research questions above and the related findings, and the discussion section focused on the findings regarding the results of the study.

\section{Method}

This study has been designed as a correlational research in which the researcher measures two or more variables and assesses the statistical relationship between those variables (Fraenkel et al. 2012). Statistical techniques such as correlation analysis, multivariate regression equation were designed to explore students' e-learning readiness and knowledge sharing levels and the authors investigated the causal relationship among to compare the students' computer, mobile phone and tablet using skills and duration of use. In other words, this descriptive correlational study examines the level of medical students' readiness for e-learning and knowledge sharing 
behaviors in emergency remote learning environments by analyzing whether there is any correlation between several variables.

\section{Participants}

The research was conducted at Çanakkale Onsekiz Mart University, Faculty of Medicine with the approval of the Scientific Research Ethics Committee, Çanakkale Onsekiz Mart University (18/12/2020-07/16). The data were collected during the COVID-19 pandemic. In this period, medical students (year 1-3) conducted their studies online, 4th and 5th year students through hybrid (online learning-face-to-face) learning, and 6th year students through face-to-face learning environments. Therefore, the Ethics Committee suggested that the data should be collected online, and the data collection form was uploaded to university online platform. In this platform, the students were asked to read the related information about the research and give their consent if they would like to participate in the study. The students who did not accept to participate did not see the scale items related to the study. In this way, data were obtained from 725 students in total out of 994 students (according to 2020-2021 Academic Year) who study at the Faculty of Medicine, Çanakkale Onsekiz Mart University. The participation rate to the study is $\% 73$, which indicates that the data could not be obtained from the entire population. Therefore, purposive sampling method was adopted. The researchers, while using purposive sampling, determine the characteristics of the people who will form the research population and they aim to reach the people who have these characteristics. Based on the information about the population, the subjects who can provide the best information for the purpose of the research are selected (Christensen et al., 2014; McMillan \& Schumacher, 2014). 398 of the participants $(54.9 \%)$ are female and $327(45.1 \%)$ are male [173 (23.9\%) Year 1, $175(24.1 \%)$ Year 2, $114(15.7 \%)$ Year 3, $112(15.4 \%)$ Year 4, $94(13 \%)$ Year 5 and 57 (7.9\%) Year 6 students].

\section{Data Collection Tools}

In this study, the data were collected through two different tools described as follows;

Knowledge Sharing Behavior in Online Learning Environments Scale (KSBOLES): The scale developed by Tseng and Kuo (2014) was adapted to Turkish by Avcı Yücel and Ergün (2015). The scale aims to examine how students perceive themselves in terms of knowledge sharing in online learning environments. The adaptation study was carried out with the data collected from university students. The scale consists of two subscales: knowledge receiving (Item 1, 2, 3 and 4) and knowledge giving (Item 5, 6, 7, 8 and 9), and it was designed using 7-point Likert structure. There are no reverse scored items in the scale. In the adaptation of the scale into Turkish culture, the confirmatory factor analysis fit-indexes were determined as $\mathrm{X} 2 / \mathrm{df}=2.41$, RMSEA=.07, $\mathrm{SRMR}=.03, \mathrm{GFI}=.92, \mathrm{CFI}=.99, \mathrm{NNFI}=.98$ and $1 \mathrm{fl}=.99$. The Cronbach Alpha reliability co-efficient of the scale was determined as .90 .

E-Learning Readiness Self-Assessment Instrument (ELRSAI): The scale developed by Watkins et al. (2004) was adapted to Turkish by Kalelioğlu and Huri Baturay (2014). The scale aims to assess students' readiness for elearning. The adaptation was carried out with the data collected from university students. The scale has 6 subscales: technology access (Item 1-3), technical skills (Item 4-7), online relationships (Item 8-12), motivation (Item 17-19), online skills (Item 17-19) and importance of success (Item 20-25). It was designed using 5-point Likert structure. There are no reverse scored items in the scale. The Cronbach Alpha reliability co-efficient of the subscale of the scale was vary between .64 and .84 .

Apart from the scales above, the students were also asked four questions about their gender, years of study at the faculty of medicine, ability to use different electronic devices for e-learning (computer, mobile phone, tablet PC, etc.) time spent on the computer, mobile phone and tablet PC per day. However, the gender and years of study variables were not used in any analyses.

\section{Data Analysis}

The data were analyzed using $\mathrm{R}$ statistical software. Students' e-learning readiness and knowledge sharing behavior levels were analyzed using descriptive statistics (mean, standard deviation, median, etc.). The relationship between the variables was modeled using multivariate regression equation. Students' e-learning readiness and knowledge sharing levels were compared using the MANOVA test according to their computer, 
mobile phone and tablet using skills and duration of use. For multivariate regression modeling, the prerequisite for the data to have a normal distribution was ignored.

Tests which focus on normality are hypersensitive tests (Tabachnick \& Fidell, 2013). In addition, in many studies, especially in social sciences, the measurement of dependent variables does not correspond to normal distribution (Pallant, 2016). The Central Limit Theorem suggests that if the sample is large enough $(n=30+)$, the sampling distribution of the mean will be normally distributed regardless of the distribution of the variables, and the normal distribution violation will not cause a major problem (Everitt \& Howell, 2005; Field, 2018; Pallant, 2016; Tabachnick \& Fidell, 2013). In large samples, skewness does not deviate from normal distribution significantly. In other words, if the data set is more than 200, the data is considered normal and parametric tests are applied (Tabachnick and Fidel, 2013). Within this context, multivariate regression analysis and MANOVA were used to analyze the data.

\section{Results}

\section{Medical Students' Knowledge Sharing Behaviors in Online Learning Environments}

Knowledge Sharing Behavior in Online Learning Environments Scale (KSBOLES) was applied to the participants. The descriptive statistics of the responses given by 725 students (from year 1 to year 6 ) are shown in Table 1.

Table 1. Medical students' knowledge sharing behaviors in online learning environments

\begin{tabular}{|c|c|c|}
\hline Items of Knowledge Sharing Behavior in Online Learning Environments Scale & $\begin{array}{l}\text { Mean (Std. } \\
\text { Deviation) }\end{array}$ & $\begin{array}{c}\text { Median } \\
\text { (Min-Max) }\end{array}$ \\
\hline I read other members' posts in online environments. & $4.64(1.65)$ & $4(1-7)$ \\
\hline I download the educational resources in online environments. & $4.76(1.68)$ & $5(1-7)$ \\
\hline $\begin{array}{l}\text { I get other members' learning experiences, knowledge and skills in online } \\
\text { environments. }\end{array}$ & $4.61(1.61)$ & $4(1-7)$ \\
\hline I read other members' sharings in online environments. & $4.65(1.63)$ & $4(1-7)$ \\
\hline I often respond to the topics discussed in online environments. & $3.92(1.62)$ & $4(1-7)$ \\
\hline I often upload educational resources to online environments. & $3.75(1.74)$ & $4(1-7)$ \\
\hline I often share my own learning experience, knowledge and skills in online environments. & $3.83(1.63)$ & $4(1-7)$ \\
\hline I often share my emotion in online environments. & $3.64(1.69)$ & $4(1-7)$ \\
\hline I often express my concerns in online environments. & $3.78(1.70)$ & $4(1-7)$ \\
\hline
\end{tabular}
$\mathrm{N}=725$

"Reading other members' posts", “downloading the educational resources", "getting other members' learning experiences, knowledge and skills" and "reading other members' sharings..." are the items with highest scores in KSBOLES. These items are related to the factor "knowledge receiving" in the scale. The scores of the responses given for the factor "knowledge giving" is lower.

\section{Medical Students' E-learning Readiness Levels}

In the study, "E-Learning Readiness Self-Assessment Instrument (ELRSAI)" was also applied to the students. The descriptive statistics of the responses given by 725 students from the year 1-6 are shown in Table 2 . The items with highest scores in ELRSAI are:

- Having access to a computer with internet connection

- Having basic skills to operate a computer

- Having basic skills for finding the way around the Internet

- $\quad$ Ability to send an email with a file attached

- $\quad$ Ability to communicate effectively with others using online technologies

- The importance of having regular contact with the instructor

- The importance of quick technical and administrative support to succeed in online coursework,

- The importance of frequent participation throughout the learning process ö

- $\quad$ The ability to immediately apply course materials 
Table 2. Medical students' e-learning readiness levels

\begin{tabular}{|c|c|c|}
\hline Items of E-Learning Readiness Self-Assessment Instrument & $\begin{array}{l}\text { Mean (Std. } \\
\text { Deviation) }\end{array}$ & $\begin{array}{l}\text { Median } \\
\text { (Min-Max) }\end{array}$ \\
\hline I have access to a computer with an Internet connection. & $3.70(1.19)$ & $4(1-5)$ \\
\hline I have access to a fairly new computer (e.g., enough RAM, speakers, CD-ROM). & $3.20(1.23)$ & $3(1-5)$ \\
\hline $\begin{array}{l}\text { I have access to a computer with adequate software (e.g., Microsoft Word, Adobe } \\
\text { Acrobat). }\end{array}$ & $3.40(1.17)$ & $3(1-5)$ \\
\hline I have the basic skills to operate a computer (e.g., saving files, creating folders). & $3.74(1.10)$ & $4(1-5)$ \\
\hline $\begin{array}{l}\text { I have the basic skills for finding my way around the Internet (e.g., using search } \\
\text { engines, entering passwords). }\end{array}$ & $3.83(1.08)$ & $4(1-5)$ \\
\hline I can send an email with a file attached. & $3.81(1.08)$ & $4(1-5)$ \\
\hline $\begin{array}{l}\text { I think that I would be comfortable using a computer several times a week to } \\
\text { participate in a course. }\end{array}$ & $3.47(1.11)$ & $3(1-5)$ \\
\hline $\begin{array}{l}\text { I think that I would be able to communicate effectively with others using online } \\
\text { technologies (e.g., email, chat). }\end{array}$ & $3.50(1.11)$ & $4(1-5)$ \\
\hline $\begin{array}{l}\text { I think that I would be able to express myself clearly through my writing (e.g., } \\
\text { mood, emotions, and humor). }\end{array}$ & $3.39(1.12)$ & $3(1-5)$ \\
\hline $\begin{array}{l}\text { I think that I would be able to use online tools (e.g., email, chat) to work on } \\
\text { assignments with students who are in different time zones. }\end{array}$ & $3.46(1.11)$ & $3(1-5)$ \\
\hline $\begin{array}{l}\text { I think that I would be able to schedule time to provide timely responses to other } \\
\text { students and/or the instructor. }\end{array}$ & $3.41(1.08)$ & $3(1-5)$ \\
\hline I think I am able to chat with others via internet (e.g., Messenger). & $3.57(1.08)$ & $4(1-5)$ \\
\hline $\begin{array}{l}\text { I think that I would be able to remain motivated even though the instructor is not } \\
\text { online at all times }\end{array}$ & $3.10(1.12)$ & $3(1-5)$ \\
\hline $\begin{array}{l}\text { I think that I would be able to complete my work even when there are online } \\
\text { distractions (e.g., friends sending emails or Websites to surf). }\end{array}$ & $3.25(1.09)$ & $3(1-5)$ \\
\hline $\begin{array}{l}\text { I think that I would be able to complete my work even when there are distractions } \\
\text { in my home (e.g., television, children, and such). }\end{array}$ & $3.08(1.14)$ & $3(1-5)$ \\
\hline $\begin{array}{l}\text { I think that I would be able to carry on a conversation with others using the } \\
\text { Internet (e.g., Internet chat, instant messenger). }\end{array}$ & $3.20(1.12)$ & $3(1-5)$ \\
\hline I think that I would be able to take notes while watching a video on the computer. & $3.32(1.09)$ & $3(1-5)$ \\
\hline $\begin{array}{l}\text { I think that I would be able to understand course related information when it's } \\
\text { presented in video formats }\end{array}$ & $3.33(1.07)$ & $3(1-5)$ \\
\hline $\begin{array}{l}\text { I think that I would be comfortable having several discussions taking place in the } \\
\text { same online chat even though I may not be participating in all of them. }\end{array}$ & $3.32(1.05)$ & $3(1-5)$ \\
\hline I sometimes prefer to have more time to prepare responses to a question. & $3.62(1.06)$ & $4(1-5)$ \\
\hline $\begin{array}{l}\text { Regular contact with the instructor is important to my success in online } \\
\text { coursework. }\end{array}$ & $3.55(1.08)$ & $4(1-5)$ \\
\hline $\begin{array}{l}\text { Quick technical and administrative support is important to my success in online } \\
\text { coursework. }\end{array}$ & $3.59(1.06)$ & $4(1-5)$ \\
\hline $\begin{array}{l}\text { Frequent participation throughout the learning process is important to my success } \\
\text { in online coursework. }\end{array}$ & $3.51(1.05)$ & $4(1-5)$ \\
\hline $\begin{array}{l}\text { I feel that prior experiences with online technologies (e.g., email, Internet chat, } \\
\text { online readings) are important to my success with online course. }\end{array}$ & $3.61(1.05)$ & $4(1-5)$ \\
\hline $\begin{array}{l}\text { The ability to immediately apply course materials is important to my success with } \\
\text { online courses. }\end{array}$ & $3.61(1.05)$ & $4(1-5)$ \\
\hline
\end{tabular}
$\mathrm{N}=725$

\section{The Prediction Level of Readiness for E-Learning on Knowledge Sharing Behaviors in Online Learning Environments}

The items with high scores are related to the subscales of "technical skills" and "importance to your success". The impact of medical students' readiness for e-learning on their knowledge sharing behaviors in online learning environments was modeled using multivariate regression analysis. The results are shown in Table 3. 
Table 3. The prediction level of readiness for e-learning on knowledge sharing behaviors in online learning environments

\begin{tabular}{llccccc}
\hline \multirow{2}{*}{ Estimated } & \multicolumn{1}{c}{ Predictor } & \multirow{2}{*}{ Coefficient } & $\mathrm{p}$ & \multicolumn{2}{c}{ 95\% Confidence Interval } & \multirow{2}{*}{$R^{2}$} \\
& Technology Access & 0.20 & 0.081 & -0.02 & 0.43 \\
& Technical Skills & -0.74 & 0.0001 & -0.99 & -0.47 \\
\multirow{3}{*}{ Knowledge Giving } & Online Relationships & 0.46 & 0.0001 & 0.26 & 0.66 & 0.27 \\
& Motivation & 0.59 & 0.0001 & 0.39 & 0.79 & \\
& Online Skills & 0.22 & 0.191 & -0.11 & 0.55 & \\
& Importance of Success & 0.13 & 0.095 & -0.02 & 0.28 \\
\hline \multirow{5}{*}{ Knowledge } & Technology Access & 0.13 & 0.127 & -0.04 & 0.29 \\
& Technical Skills & 0.25 & 0.009 & 0.06 & 0.44 \\
& Online Relationships & 0.14 & 0.062 & -0.01 & 0.29 & 0.46 \\
& Motivation & -0.11 & 0.118 & -0.26 & 0.03 & \\
& Online Skills & -0.03 & 0.816 & -0.26 & 0.21 & 0.58 \\
\hline
\end{tabular}

"Online relationships" and "motivation", the subscales of readiness for e-learning scale, are positive predictors for the knowledge giving subscales of knowledge sharing behavior scale $(\mathrm{p}<.05)$. Therefore, the increase in the readiness levels in terms of "online relationships" and "motivation" will also increase "knowledge giving". "Technical skills", one of the subscales of readiness for e-learning scale, is a negative predictor for the "knowledge giving" subscales of the knowledge sharings behaviors scale $(\mathrm{p}<.05)$. In other words, the increase in the "technical skills" readiness will decrease the level of knowledge giving. "Technical skills" and "importance of success", the subscales of readiness for e-learning scale, are positive predictors for "knowledge receiving", one of the subscales of knowledge sharing behavior scale $(\mathrm{p}<.05)$. In other words, the increase in the "technical skills" and "importance of success" readiness levels also increases the level of "knowledge receiving". The exploratory regression percentage for "knowledge receiving" (R2=0.46, 46\%) is higher than the percentage for "knowledge giving" (R2=0.27, 27\%).

\section{The Comparison of Students' E-Learning Readiness and Knowledge Sharing Levels in terms of Their Computer, Mobile Phone and Tablet Using Skills and Time Spent on Computer}

Students' e-learning readiness and knowledge sharing levels were compared using the MANOVA test according to their computer, mobile phone and tablet using skills and exposure time of use. The results are indicated in Table 4.

Table 4. The comparison of students' e-learning readiness and knowledge sharing levels according to their computer, mobile phone and tablet using skills and time spent on computer, etc. (MANOVA Test)

\begin{tabular}{lcccccc}
\hline \multicolumn{1}{c}{ Effect } & Value & $\mathrm{F}$ & $\begin{array}{c}\text { Hypothesis } \\
\text { df }\end{array}$ & $\begin{array}{c}\text { Error } \\
\text { df }\end{array}$ & $\mathrm{p}$ & $\eta^{2}$ \\
\hline Computer using skills & 0.09 & 4.02 & 16 & 1420 & 0.000 & 0.04 \\
Time spent on computer, etc. & 0.03 & 1.35 & 16 & 1420 & 0.158 & 0.02 \\
$\begin{array}{l}\text { Computer using skills *Time } \\
\text { spent on computer, etc. }\end{array}$ & 0.05 & 1.21 & 32 & 2848 & 0.192 & 0.01 \\
\hline
\end{tabular}

The level of computer, mobile phone and tablet using skills create a significant difference between the students' readiness for e-learning and knowledge sharing behaviors in online learning environments $(\mathrm{F}(16-1420)=4.02$, $\mathrm{p}<.05)$. this significant difference refers to medium effect size $(\eta 2=0.04)$ according to the classification proposed by Cohen et al. (2013). According to MANOVA test results, the time spent on computer, mobile phones and tablet PCs do not have a significant effect on the level of students' readiness for e learning and knowledge sharing behaviors in online learning environments $(F(16-1420)=1.35, p>.05)$. The interaction of the two main effects (interaction of the ability to use computer, mobile phone, tablet PC and time spent on these devices) does not make a significant difference between the levels of students' readiness for e-learning and knowledge sharing behaviors in online learning environments $(\mathrm{F}(32-2848)=1.21, \mathrm{p}>.05)$. The results of the analysis about which the sub-factors have a significant difference between the levels of students' readiness for e-learning and knowledge sharing behaviors are shown in Table 5. 
Table 5. The comparison of students' readiness for e-learning and knowledge sharing behaviors in online learning environments in terms of ability to use computer, mobile phone, tablet PC

\begin{tabular}{|c|c|c|c|c|c|c|c|}
\hline \multicolumn{2}{|c|}{ Dependent Variable } & $\begin{array}{l}\text { Sum of } \\
\text { Squares }\end{array}$ & df & $\begin{array}{l}\text { Mean } \\
\text { Square }\end{array}$ & $\mathrm{F}$ & $\mathrm{p}$ & $\eta^{2}$ \\
\hline \multirow{2}{*}{ Knowledge Giving } & Contrast & 1065.63 & 2 & 532.81 & \multirow{2}{*}{9.87} & \multirow{2}{*}{0.000} & \multirow{2}{*}{0.03} \\
\hline & Error & 38649.51 & 716 & 53.98 & & & \\
\hline \multirow{2}{*}{ Knowledge Receiving } & Contrast & 1404.53 & 2 & 702.26 & \multirow{2}{*}{19.95} & \multirow{2}{*}{0.000} & \multirow{2}{*}{0.05} \\
\hline & Error & 25198.72 & 716 & 35.19 & & & \\
\hline \multirow{2}{*}{ Technology Access } & Contrast & 296.20 & 2 & 148.10 & \multirow{2}{*}{15.26} & \multirow{2}{*}{0.000} & \multirow{2}{*}{0.04} \\
\hline & Error & 6948.92 & 716 & 9.71 & & & \\
\hline \multirow{2}{*}{ Technical Skills } & Contrast & 500.49 & 2 & 250.25 & \multirow{2}{*}{17.07} & \multirow{2}{*}{0.000} & \multirow{2}{*}{0.05} \\
\hline & Error & 10499.14 & 716 & 14.66 & & & \\
\hline \multirow{2}{*}{ Online Relationships } & Contrast & 846.93 & 2 & 423.46 & \multirow{2}{*}{18.95} & \multirow{2}{*}{0.000} & \multirow{2}{*}{0.05} \\
\hline & Error & 15997.89 & 716 & 22.34 & & & \\
\hline \multirow{2}{*}{ Motivation } & Contrast & 283.59 & 2 & 141.79 & \multirow{2}{*}{9.51} & \multirow{2}{*}{0.000} & \multirow{2}{*}{0.03} \\
\hline & Error & 10677.44 & 716 & 14.91 & & & \\
\hline \multirow{2}{*}{ Online Skills } & Contrast & 174.82 & 2 & 87.41 & \multirow{2}{*}{11.26} & \multirow{2}{*}{0.000} & \multirow{2}{*}{0.03} \\
\hline & Error & 5558.58 & 716 & 7.76 & & & \\
\hline \multirow{2}{*}{ Importance of Success } & Contrast & 856.16 & 2 & 428.08 & \multirow{2}{*}{13.44} & \multirow{2}{*}{0.000} & \multirow{2}{*}{0.04} \\
\hline & Error & 22813.18 & 716 & 31.86 & & & \\
\hline
\end{tabular}

According to the analysis, the ability to use computer, mobile phone and tablet PC have a significant difference on all subscales $(\mathrm{p}<.05)$. All these differences were at medium effect size. According to Bonferroni post-hoc test, which was applied to see if these significant differences are in favor of the students with poor, adequate or high-level ability to use computers, mobile phones and tablet PCs. The results revealed that it is in favor of the students with high level ability to use these devices. To sum up, the students with high ability to use computer, mobile phone and tablet PC have higher readiness level for e-learning in terms of technology access, technical skills, online relationships, motivation, online skills, importance of success. Similarly, they have a higher level of knowledge sharing behaviors in online learning environments.

\section{Discussion}

As part of this research, we examined the medical students' readiness for e-learning and knowledge sharing behaviors in online learning environments during Covid-19 and explored the relationship between these variables. First, the responses the students gave for the items in the "knowledge sharing behaviors in online learning environment" scale revealed that they agree more with the items related to knowledge receiving than the items about knowledge giving. This finding is in line with the study conducted by Chao, Hwu and Chang (2011). This may have resulted from the fact that they do not find the online learning environment engaging enough or they feel alone during the online learning practices, and they prefer receiving knowledge more than sharing their own knowledge with others. While we, as educators, aim to develop students skills to be independent and self-directed learners, we should also be careful about the issue that the students may be isolated from each other if they do not interact with each other. This may result in lack of student collaboration, interaction with the instructor and other students, and cause troubles in creating a learning community. In other words, we shouldn't ignore the improvement of social competences while trying to develop their technical or professional competences.

Second, the increase in the readiness level in terms of online relationships and motivation also increases the knowledge giving in online learning environments. This means that when students feel ready for online learning, they are motivated and intend to have more relationship with others in the online learning environments. This finding correlates with the study by Joosten and Cusatis (2020). However, the increase in the readiness level in terms of technical skills has a decreasing role on knowledge giving in online learning environments. But the increase in the readiness level in terms of technical skills and importance of success increases the knowledge receiving behaviors of the students. This reverse affect may have resulted from the idea that the students feel more independent to learn as they have enough technological skills, and therefore, they do not feel the need to give knowledge by engaging with others, but they still intend to receive knowledge in the online environments. Another reason may be the fact that they do not want to share their knowledge as they do not think that the others will be interested in what they share. 
Finally, the students with high ability levels to use computer, mobile phone and tablet PC have higher readiness level for e-learning in terms of technology access, technical skills, online relationships, motivation, online skills, importance of success. This finding is in line with the research conducted by Forson and Vuopala (2019) in that students' skills in ICT is an important factor that contributes student readiness. Similarly, it correlates with the findings of the studies by Rahardjo (2018) and Martin, Stamper and Flowers (2020) in that knowledge and ability to use these tools increase student motivation and the expectation of success. However, the time spent on computers, mobile phones or tablet PCs does not affect the level of students' readiness for e-learning and/or knowledge sharing behaviors in online learning environments.

\section{Limitations}

This study has a limitation in that the data were obtained from only one medical faculty although there are a lot of medical faculties in Turkey. Therefore, collecting the data from a larger sample could have increased the generalizability of the results. In this context, further research can be conducted with larger samples and can be compared with the findings of our study.

\section{Conclusion}

Although the term "emergency" in remote learning sounds "strict" or "rough" at first sight, having experience in digital learning environments will definitely increase students' readiness for e-learning which is quite useful for the educational practices during and possibly after Covid-19 pandemic. This study revealed that medical students' readiness for e-learning is high in terms of knowledge receiving rather than knowledge giving. This shows us that the medical students who participated in this study prefers learning from others rather than sharing the knowledge they have. However, sharing knowledge is a voluntary action and so does their profession; therefore, medical students' knowledge sharing behaviors should also be developed in order to create a sense of learning community. And it is more important for medical students who will work collaboratively in a team to gain such competences as well as learning hands-on clinical skills. Therefore, online learning environments should be designed to promote students' knowledge sharing behaviors. This will not only motivate them learn from each other but also help to get necessary skills (e.g., teamwork, communication, etc.) required for their future profession. To achieve this, medical educators should also be provided with the trainings about how to create a knowledge sharing culture in online learning environments and how to adapt their teaching strategies to enhance knowledge sharing activities more.

We believe that the results of our study will contribute to highlight the essential knowledge and skills that the students should have in order to increase their readiness level for e-learning in terms of technology access, technical skills, online relationships, motivation, online skills, importance of success. In addition, this study reveals original results as it focused on the medical students' readiness for e-learning and knowledge sharing behaviors in emergency remote learning environments during Covid-19. As medical education adopts a more practice or clinical based approach in terms of learning environments, online learning may be considered inadequate for medical students to gain the required knowledge, skills and competences. However, they also need to gain some process skills in addition to technical/clinical skills, and both educators and students should be aware of the fact that, even if it is online, the learning environment should be designed properly to foster these skills. Further research should focus on analyzing the students' e-learning and knowledge sharing behaviors with a larger sample size from different medical faculties and several research can be conducted to investigate about what factors affect the medical students' e-learning readiness and knowledge sharing behaviors.

\section{Scientific Ethics Declaration}

The authors declare that the scientific ethical and legal responsibility of this article published in JESEH journal belongs to the authors.

\section{Acknowledgements or Notes}

The authors gratefully acknowledge the support of the medical students who voluntarily participated in this 
study at Çanakkale Onsekiz Mart University, Faculty of Medicine.

\section{References}

Adedoyin, O. B., \& Soykan, E. (2020). Covid-19 pandemic and online learning: the challenges and opportunities. Interactive Learning Environments, 1-13. https://doi.org/10.1080/10494820.2020. 1813180

Affouneh, S., Salha, S., \& Khlaif, Z. N. (2020). Designing quality e-learning environments for emergency remote teaching in coronavirus crisis. Interdisciplinary Journal of Virtual Learning in Medical Sciences, 11(2), 135-137.

Arkorful, V., \& Abaidoo, N. (2015). The role of e-learning, advantages and disadvantages of its adoption in higher education. International Journal of Instructional Technology and Distance Learning, 12(1), 2942.

Avc1 Yücel, Ü., \& Ergün, E. (2015). Adaptation of the knowledge sharing behavior in online learning environments scale to Turkish: A validity and reliability study, Başkent University Journal of Education (BUJE), 2(2), 219-228.

Cameron-Standerford, A., Menard, K., Edge, C. U., Bergh, B., Shayter, A., Smith, K., \& VandenAvond, L. (2020). The phenomenon of moving to online/distance delivery as a result of Covid-19: Exploring initial perceptions of higher education faculty at a rural Midwestern university. In Frontiers in Education, Vol. 5, p. 203. Frontiers.

Chao, C.-Y., Hwu, S.-L., \& Chang, -C.-C. (2011). Supporting interaction among participants of online learning using the knowledge sharing concept. Turkish Online Journal of Educational Technology, 10(4), 311319.

Christensen, L. B., Johnson, R. B. \& Turner, L. A. (2014). Research methods, design, and analysis. The USA: Pearson Education.

Cohen, J., Cohen, P., West, S. G., \& Aiken, L. S. (2013). Applied multiple regression/correlation analysis for the behavioral sciences. Routledge.

Dabbagh, N. (2007). The online learner: characteristics and pedagogical implications. Contemporary Issues in Technology and Teacher Education, 7(3), 217-226.

Elrehail, H., Emeagwali, O. L., Alsaad, A., \& Alzghoul, A. (2018). The impact of transformational and authentic leadership on innovation in higher education: the contingent role of knowledge sharing. Telematics and Informatics, 35(1), 55-67.

Everitt, B. S., \& Howell, D. C. (2005). Encyclopedia of statistics in behavioral science. The UK: John Willey and Sons.

Ferri, F., Grifoni, P., \& Guzzo, T. (2020). Online learning and emergency remote teaching: Opportunities and challenges in emergency situations. Societies, 10(4), 1-18.

Field, A. (2018). Discovering statistics using IBM SPSS Statistics. The USA: Sage.

Forson, I. K., \& Vuopala, E. (2019). Online learning readiness: perspective of students enrolled in distance education in Ghana. The Online Journal of Distance Education and e-Learning, 7(4), 277-294.

Fraenkel, J. R., Wallen, N. E., \& Hyun, H. H. (2012). How to design and evaluate research in education. USA: McGraw Hill.

Han, S.J., Lee, Y., Beyerlein, M. \& Kolb, J. (2018). Shared leadership in teams: The role of coordination, goal commitment, and knowledge sharing on perceived team performance. Team Performance Management, 24(4), 150-168. https://doi.org/10.1108/TPM-11-2016-0050

Hodges, C., Moore, S., Lockee, B., Trust, T., \& Bond, A. (2020). The difference between emergency remote teaching and online learning. Educause Review. https://er.educause.edu/articles/2020/3/thedifferencebetween-emergency-remote-teaching-and-online-learning

Joosten, T., \& Cusatis, R. (2020). Online learning readiness. American Journal of Distance Education, 34(3), 180-193.

Kalelioglu, F., \& Baturay, M. H. (2014). daptation of e-learning readiness self-assessment instrument to Turkish: The validity and reliability study. Başkent University Journal of Education (BUJE), 1(2), 2230.

Korkmaz, G. \& Toraman, Ç. (2020). Are we ready for the post-COVID-19 educational practice? An investigation into what educators think as to online learning. International Journal of Technology in Education and Science (IJTES), 4(4), 293-309.

Ma, W. W., \& Yuen, A. H. (2011). Understanding online knowledge sharing: An interpersonal relationship perspective. Computers \& Education, 56(1), 210-219.

Martin, F., Stamper, B., \& Flowers, C. (2020). Examining student perception of readiness for online learning: importance and confidence. Online Learning, 24(2), 38-58. 
McMillan, J., \& Schumacher, S. (2014). Research in education evidence based inquiry. The UK: Pearson Education.

Pallant, J. (2016). SPSS survival manual. The USA: McGraw-Hill Education.

Pillay, H., Irving, K., \& Tones, M. (2007). Validation of the diagnostic tool for assessing tertiary students' readiness for online learning. High Education Research \& Development, 26(2), 217-234.

Rahardjo, D. (2018). E-learning readiness and technology adoption in online tutorial. In Proceedings of the 32nd Annual Conference of the Asian Association of Open Universities (AAOU) 2018: Open Education in Human Resource Development in Asia's Period of Integration.

Shim, T. E., \& Lee, S. Y. (2020). College students' experience of emergency remote teaching due to COVID19. Children and Youth Services Review, 119, 105578.

Smith, P. J. (2005). Learning preferences and readiness for online learning. Educational Psychology, 25(1), 312.

Tabachnick, B. G., \& Fidell, L. S. (2013). Learning preferences and readiness for online learning. Educational Psychology, 25(1), 3-12.

Tseng, F. C. \& Kuo, F.Y. (2014). A study of social participation and knowledge sharing in the teachers' online professional community of practice. Computers \& Education, 72, 37-47.

Wang, S., \& Noe, R. A. (2010). Knowledge sharing: A review and directions for future research. Human Resource Management Review, 20(2), 115-131.

Wang, G., Zhang, Y., Zhao, J., Zhanh, J., \& Jianh, F. (2020). Mitigate the effects of home confinement on children during the COVID-19 outbreak. The Lancet, 395(10228), 21-27.

Watkins, R., Leigh, D., \& Triner, D. (2004). Assessing readiness for e-learning. Performance Improvement Quarterly, 17(4), 66-79. https://doi.org/10.1111/j.1937-8327.2004.tb00321.x

\section{Author(s) Information}

\begin{tabular}{ll}
\hline Güneş Korkmaz & Çetin Toraman \\
Özel Ege Lisesi, Department of Foreign Languages, İzmir, & Çanakkale Onsekiz Mart University, Faculty of Medicine, \\
35100 & Terzioğlu Campus, Çanakkale, 17020 \\
Turkey & Turkey \\
Contact e-mail: gunes.korkmaz.gk@gmail.com & ORCID ID: https://orcid.org/0000-0001-5319-0731 \\
ORCID ID: https://orcid.org/0000-0002-9060-5972 &
\end{tabular}

